\title{
A novel metalloprotease from Bacillus cereus for protein fibre processing
}

\author{
Fernanda Sousa $^{\text {a }}$, Susana Jus ${ }^{\mathrm{b}}$, Anita Erbel ${ }^{\mathrm{c}}$, Vanja Kokol ${ }^{\mathrm{b}}$, \\ Artur Cavaco-Paulo $^{\mathrm{d}}$, G.M. Gubitz ${ }^{\mathrm{a}, *}$ \\ ${ }^{a}$ Graz University of Technology, Environmental Biotechnology, Petersgasse 12, 8010 Graz, Austria \\ ${ }^{\mathrm{b}}$ Department of Textile Engeneering, Maribor University, Smetanova 17, SI-2000 Maribor, Slovenia \\ ${ }^{\mathrm{c}}$ Reserach Centre Applied Biocatalysis, Petersgasse 14, A-8010 Graz, Austria \\ ${ }^{\mathrm{d}}$ Department of Textile Engineering, Minho University, Campus Azruém, 4800 Guimaraes, Portugal
}

Received 25 September 2006; received in revised form 15 December 2006; accepted 18 December 2006

\begin{abstract}
A novel protease produced by Bacillus cereus grown on wool as carbon and nitrogen source was purified. $B$. cereus protease is a neutral metalloprotease with a molecular mass of $45.6 \mathrm{kDa}$. The optimum activity was at $45^{\circ} \mathrm{C}$ and $\mathrm{pH} 7.0$. The substrate specificity was assessed using oxidized insulin B-chain and synthetic peptide substrates. The cleavage of the insulin B-chain was determined to be Asn ${ }^{3}, \mathrm{Leu}^{6}, \mathrm{His}^{10}{ }^{\mathrm{L}} \mathrm{Leu}^{11}, \mathrm{Ala}^{14}$, $\mathrm{Glu}^{21}$, after $12 \mathrm{~h}$ incubation. Among the peptide substrates, the enzyme did not exhibit activity towards ester substrates; with $p$-nitroanilide, the kinetic data indicate that aliphatic and aromatic amino acids were the preferred residues at the $\mathrm{P}_{1}$ position. For furylacryloyl peptides substrates, which are typical substrates for thermolysin, the enzyme exhibited high hydrolytic activity with a $K_{\mathrm{m}}$ values of 0.858 and $2.363 \mathrm{mM}$ for $N$-(3[2-Furyl]acryloyl)-Ala-Phe amide and $N$-(3-[2-Furyl]acryloyl)-Gly-Leu amide, respectively. The purified protease hydrolysed proteins substrates such as azocasein, azocoll, keratin azure and wool.
\end{abstract}

(C) 2007 Elsevier Inc. All rights reserved.

Keywords: Metalloprotease; Specificity; Kinetics; Wool fibre

\section{Introduction}

The wool surface morphology requires a special wool textile finishing process. The cuticle cells (or scales) of wool fibres overlap with each other forming the surface of the wool. They are largely responsible for important properties of wool such as wettability, felting behaviour, dyeability and printability. The high concentration of cystine crosslinkages on wool surface is a special feature of keratin fibres. Reaction of cystine crosslinkages with oxidants and reductants are of major importance, being an integral part of the wool chemistry involved in isolating wool proteins [1]. This component of the keratin structure contributes largely to the physical and mechanical properties of the wool fibre. The hydrophobic character and the exposed edges of the cuticle cells are responsible for a differential-friction effect (DFE) resulting in all fibres to move to their root end when mechanical action is applied in the wet state [2,3]. It is well

\footnotetext{
* Corresponding author.

E-mail address: guebitz@tugraz.at (G.M. Gubitz).
}

known that the DFE results in the felting shrinking of wool. Therefore, the most successful and commercial shrink-proofing processes are based on modification of fibre surface either by oxidative or reductive methods and/or by the application of a polymer resin onto the surface. The most frequently used commercial process (the chlorine/Hercosett process) consists of a chlorination step followed by a dechlorination step and polymer application [4]. Although this process is highly efficient in reducing shrinking, chlorination produces adsorbable organohalogens (AOX) which appear in the effluent and generate toxicity. With the increasing of ecological and economical restrictions imposed to the textile industry, industries are required to find environmentally favourable alternatives in wool treatment processes [5]. In addition, coating with synthetic polymers largely compromises the natural feeling of wool. The applications of biopolymers has been investigated as possible substitution [6], but until now were not successful in conferring degrees of resistance.

As an alternative, wool can be treated by enzymes, especially proteolytic enzymes, in order to develop environmentally friendly alternative processes. Enzyme technology, especially protease technology, has been explored intensively [7], alone 
or in combined processes [8]. To improve the proteolytic anti-shrinkage process, different types of proteases have been studied. A thermo- and alkaliphilic protease has been applied on an industrial scale in the pre-washing step of a wool dyeing process [9] and a protease from Aspergillus flavus, isolated from wool, has been examined [10]. Enzymatic processes published in the recent years also comprise combined processes. One example is the enzyme incorporated in the alkaline peroxide treatment, after which chitosan is applied to the wool [11]. However, the major problem in the application of proteases to wool is due to the enzyme penetration between cuticle scales into the interior of the fibre and break down of the cell membrane complex resulting in an irreversible damage of the fibre [9].

Only very little is known about the specificity of proteases toward wool due to its heterogeneous nature and to the amount of amino acids varying depending upon the source of the wool fibre.

The present study describes the purification and characterization of new wool-degrading enzyme from Bacillus cereus with potential application for wool treatment with further incorporation in detergent formulations. B. cereus is an aerobic, endospore-forming, mobile Gram-positive rod, but grows well anaerobically, being commonly found in soil, air and water [12].

\section{Materials and methods}

\subsection{Isolation and selection of the strains}

Several different bacteria growing on wool samples [Drummond Parkland of England, Huddersfield, UK] were cultivated in minimal medium agar plates overlaid with $0.1 \mathrm{~g}$ of wool. The growth was monitored under the microscope, after staining with DAPI $\left(0.1 \mu \mathrm{g} \mathrm{ml}^{-1}\right.$ in phosphate-buffered saline $50 \mathrm{mM}$ buffer). The separation of the individual strains was made by platting on Standard I nutrient agar. After separation of colonies the different bacteria were selected based on proteolytic activity by plating on the surface of skim milk agar plates consisting of $\left(\mathrm{g}^{-1}\right)$ : 13.6 agar, 4.5 pancreatic digest casein, 2.3 yeast extract, 0.9 glucose and $90 \mathrm{ml}$ skim milk solution $(0.1 \%, \mathrm{w} / \mathrm{v})$. Plates were incubated at $30^{\circ} \mathrm{C}$ for $24 \mathrm{~h}$ and examined for clear zones around the colony, which indicates the presence of proteases. For a more specific selection, the strains with proteolytic activity on skim milk agar plates were further cultivated in a minimal medium with wool as source of carbon and nitrogen (described below).

\subsection{Growth conditions}

For enzyme production, cultivation was performed in $2000 \mathrm{ml}$ baffled flasks containing $500 \mathrm{ml}$ of minimal medium with wool as source of carbon and nitrogen at $\mathrm{pH} 7.0$, consisting of $\left(\mathrm{gl}^{-1}\right)$ : $2.5 \mathrm{KH}_{2} \mathrm{PO}_{4}, 3.0 \mathrm{~K}_{2} \mathrm{HPO}_{4}, 0.2$ $\mathrm{MgSO}_{4} \cdot 7 \mathrm{H}_{2} \mathrm{O}, 5 \mathrm{ml}$ trace elements Stelkes-Ritter, and $5 \mathrm{~g}$ of wool (the wool was washed and sterilized separately) at $30^{\circ} \mathrm{C}$ on a rotary shaker at $120 \mathrm{rpm}$ for $24 \mathrm{~h}$. The growth was monitored by RNA content and protease activity on azocasein was monitored.

\subsection{Determination of the cellular RNA content}

The RNA content was measured in order to monitor the bacterial growth in the presence of insoluble components of the cultivation medium. This assay was performed according to Benthin et al. [13]. Fermentation broth samples of $10 \mathrm{ml}$ were collected during fermentation, centrifuged in chilled test tubes, the supernatant was discarded and the cells were frozen for subsequent analysis. The cells were washed three times with $3.0 \mathrm{ml}$ cold $0.7 \mathrm{M} \mathrm{HClO}_{4}$ to destroy the cell walls of the bacteria. Then, the samples were digested with $3.0 \mathrm{ml} 0.3 \mathrm{M}$ $\mathrm{KOH}$ for $60 \mathrm{~min}$ at $37^{\circ} \mathrm{C}$ with occasional mixing in order to hydrolyse the RNA. The extracts were cooled and neutralized with $1.0 \mathrm{ml} 3.0 \mathrm{M} \mathrm{HClO}_{4}$. The post- hydrolysis supernatant was collected and the precipitate was washed twice with $4.0 \mathrm{ml}$ cold $0.5 \mathrm{M} \mathrm{HClO}_{4}$. Finally, the extracts were made up to $15.0 \mathrm{ml}$ with $0.5 \mathrm{M} \mathrm{HClO}_{4}$ and the solutions were centrifuged to remove any non-visible precipitate of $\mathrm{KClO}_{4}$ that might be in the extracts. The RNA concentration was determined by measuring the absorbance at $260 \mathrm{~nm}$ using average nucleotide data for calibration [14].

\subsection{Azocasein assay}

Proteolytic activity with azocasein (Sigma-Aldrich) was determined according the method of Tomarelli et al. [15]. Azocasein 2\% (w/v) was prepared by dissolving in $50 \mathrm{mM}$ buffer $\mathrm{pH} 7.5$. The solubility of azocasein becomes limiting at $\mathrm{pH}$ values below 6.0. After the azocasein had dissolved, it was clarified by centrifugation at $12,000 \times g$ for $10 \mathrm{~min}$. The reaction mixture containing $250 \mu \mathrm{l}$ of azocasein and $150 \mu \mathrm{l}$ of enzyme was incubated at $37^{\circ} \mathrm{C}$ for exactly $30 \mathrm{~min}$. The reaction was stopped by addition of $1.2 \mathrm{ml}$ of $10 \%$ $(w / v)$ trichloroacetic acid (TCA). After centrifugation at $8000 \times g$ for $5 \mathrm{~min}$, $1.2 \mathrm{ml}$ of the supernatant was mixed with $1.4 \mathrm{ml}$ of $\mathrm{NaOH}$ and the absorbance was determined at $440 \mathrm{~nm}$. Controls were prepared by the same procedure except that TCA was added before the enzyme. One unit of protease activity is defined to be the amount of enzyme required to produce an absorbance change of $1.0 \mathrm{~h}^{-1}$, under the conditions of the assay.

\subsection{Activity detection by zymogram activity detection}

Pre-made, commercially available $12.0 \%$ acrylamide casein zymography gels were used. Gels were inserted into a Mini-Protean 3 Cell apparatus (Bio-Rad Laboratories, Inc., Hercules, USA). The chamber was filled with $25 \mathrm{mM}$ Tris, $192 \mathrm{mM}$ glycine and $0.1 \%$ SDS buffer. Samples to test were diluted 1 part sample with 2 parts zymography sample buffer $(62.5 \mathrm{mM}$ Tris- $\mathrm{HCl}$, pH 6.8, 4.0\% SDS, $25.0 \%$ glycerol and $0.01 \%$ Bromophenol Blue) and loaded into the gel. The gel run at $100 \mathrm{~V}$ constant, $25 \mathrm{~mA}, 80-100 \mathrm{~min}$ and ended $100 \mathrm{~V}$ constant, $12 \mathrm{~mA}$. The gels were removed from the apparatus and incubated for $30 \mathrm{~min}$ at room temperature in $100 \mathrm{ml}$ of renaturation buffer $(50 \mathrm{mM}$ Tris- $\mathrm{HCl}$ buffer $(\mathrm{pH} 7.4)$ containing $2.5 \%$ Triton $\mathrm{X}-100$ ) on an orbital shaker. The renaturation buffer was removed and $100 \mathrm{ml}$ of $50 \mathrm{mM}$ Tris- $\mathrm{HCl}, \mathrm{pH} 7.5,200 \mathrm{mM} \mathrm{NaCl}, 5 \mathrm{mM}$ $\mathrm{CaCl}_{2}$ and $0.02 \%$ Brij-35 development buffer was added. Gels were incubated on the orbital shaker at room temperature overnight. The development buffer was poured off and the gels were washed with water. Coomassie Brilliant Blue R-250 was added and the gels were incubated on an orbital shaker for 30 min at room temperature. The gels were distained with $10 \%$ methanol, $5 \%$ acetic acid until clear bands appeared against the blue background.

\subsection{Purification of the protease}

The culture medium supernatant $(4000 \mathrm{ml})$ was pre-filtrated through a metallic sieve $(20 \mu \mathrm{m})$ to remove residual wool, than clarified by centrifugation to remove bacterial cells, and lyophilized. The lyophilized material was dissolved in $200 \mathrm{ml}$ of $50 \mathrm{mM}$ Tris- $\mathrm{HCl}$ buffer $\mathrm{pH} 7.5$ and frozen. After defrosting, the sample was centrifuged in order to eliminate some polysaccharides that might have precipitated. All chromatographic purification steps were carried out using an Aekta Purifier FPLC system (GE Healthcare Bio-Sciences AB, Uppsala, Sweden). Protease activities in the fractions were determined with azocasein substrate.

Samples of $10 \mathrm{ml}$ were supplemented with $0.3 \mathrm{M}\left(\mathrm{NH}_{4}\right)_{2} \mathrm{SO}_{4}$ and then loaded onto a Phenyl Sepharose CL-4B (GE Healthcare Bio-Sciences AB; $1.0 \mathrm{~cm} \times 2.5 \mathrm{~cm}$ ) column with a flow rate of $1.0 \mathrm{ml} \mathrm{min}^{-1}$, previously equilibrated with $50 \mathrm{mM}$ Tris- $\mathrm{HCl}$ buffer containing $1 \mathrm{M}\left(\mathrm{NH}_{4}\right)_{2} \mathrm{SO}_{4}$ at $\mathrm{pH}$ 7.5. The protein was eluted from the column using $50 \mathrm{mM}$ Tris- $\mathrm{HCl}$ buffer $\mathrm{pH} 7.5$ containing $15 \%$ isopropanol. The peak fractions $(1 \mathrm{ml})$ with proteolytic activity were pooled together $(10 \mathrm{ml})$ and then desalted with a Desalting Hitrap ${ }^{\mathrm{TM}}$ column (GE Healthcare Bio-Sciences AB; $1.6 \mathrm{~cm} \times 2.5 \mathrm{~cm}$ ), pre-equilibrated with $50 \mathrm{mM}$ Tris- $\mathrm{HCl}$ buffer $\mathrm{pH} 7.5$ containing $15 \%$ of isopropanol. The run was performed with a flow rate of $0.5 \mathrm{ml} \mathrm{min}-1$ and $0.5 \mathrm{ml}$ fractions were collected. Positive fractions with protease activity were collected $(2 \mathrm{ml})$ and then $0.2 \mathrm{ml}$ were loaded through Superdex 75 HR column (GE Healthcare Bio-Sciences $\mathrm{AB} ; 1.5 \mathrm{~cm} \times 12 \mathrm{~cm}$ ) previously equilibrated with $50 \mathrm{mM}$ Tris- $\mathrm{HCl}$ buffer $\mathrm{pH}$ 
7.5 containing $15 \%$ isopropanol and $200 \mathrm{mM} \mathrm{NaCl}$, with a flow of $0.5 \mathrm{ml} \mathrm{min}^{-1}$. Fractions $(1 \mathrm{ml})$ were collected and tested for protease activity and subjected to SDS-PAGE to confirm purity.

\subsection{SDS-PAGE and protein content}

SDS-PAGE was carried out by the method described by Laemmli [16] using $12 \%$ polyacrylamide resolving gels. Protein bands were visualized by staining with Coomassie Brilliant Blue R-250 Broad range pre-stained molecular weight markers (200.0-14.4 kDa) (Bio-Rad Laboratories, Inc.) were used to estimate the molecular weight of the protease.

Protein was determined by the Lowry method [17].

\subsection{Effect of inhibitors and metal ions on protease activity}

To determine the class of protease that yielded the proteolytic activity, enzymatic extract was pre-treated with following inhibitors: PMSF (serine protease inhibitor), E-64 (cysteine protease inhibitor), Pestatin A (aspartic protease inhibitor), Aprotinin (serine protease inhibitor) and EDTA (metalloprotease inhibitor). After the incubation at $37^{\circ} \mathrm{C}$ for $30 \mathrm{~min}$, the remaining activity was measured with azocasein assay.

The following metal ions were tested for their ability to stimulate or inhibit protease activity: $\mathrm{Mg}^{2+}, \mathrm{Ca}^{2+}, \mathrm{Mn}^{2+}, \mathrm{Fe}^{2+}, \mathrm{Co}^{2+}, \mathrm{Cu}^{2+}, \mathrm{Zn}^{2+}$. The assay was carried out by pre-incubation of the enzyme with the divalent cations to a final concentration of $3 \mathrm{mM}$ for $1 \mathrm{~h}$ at $37^{\circ} \mathrm{C}$ and thereafter the remaining activity was measured with azocasein assay.

Enzyme activity measured in the absence of any inhibitor or any ion was taken as $100 \%$.

\subsection{Effect of $\mathrm{pH}$ and temperature on enzyme activity and stability}

The optimum $\mathrm{pH}$ was determined at $37^{\circ} \mathrm{C}$ for $30 \mathrm{~min}$. The substrate $(2 \%$, w/v, azocasein) was prepared over a range of $\mathrm{pH}$ values between 6 and 12 in Britton-Robison universal buffer [18]. Protease activity was measured at different $\mathrm{pH}$ values under standard assay conditions. For $\mathrm{pH}$ stability, the enzyme was pre-incubated in the same buffer as above in a range of $\mathrm{pH}$ between 4 and 12 for $1 \mathrm{~h}$ at $37^{\circ} \mathrm{C}$. Then, the residual activity was determined with azocasein.

Using a standard reaction mixture for azocasein assay, the temperature optimum was a determined different temperature raging from 25 to $90^{\circ} \mathrm{C}$ for $30 \mathrm{~min}$.

The thermal stability was determined by pre-incubation of the enzyme at 37 and $50^{\circ} \mathrm{C}$ for various periods and then quickly cooled. Standard enzyme assay was used to determine the residual activity.

\subsection{Effect of various reagents on protease activity}

The stability of B. cereus protease was determined with the following reagents: detergents, SDS and Triton X-100 in a concentration of $0.1,0.5$ and 2.0\%; organic solvents: DMSO, isopropanol and acetonitrile in a concentration of 1.0, 5.0 and 20.0\%; reducing agents: DTT, thioglycolate and $\beta$-mercaptoethanol in a concentration of $10.5,2.0$ and $8.0 \%$. After pre-incubation at $37^{\circ} \mathrm{C}$ for $30 \mathrm{~min}$ with the solutions above, the residual proteolytic activity was measured under standard conditions with azocasein. A control in absence of a reagent was taken as $100 \%$.

\subsection{Azocoll assay}

Proteolytic activity with azocoll (Sigma-Aldrich) was determined according the method of Chavira et al. [19]. To $25 \mathrm{mg}$ of azocoll, $5 \mathrm{ml}$ of $100 \mathrm{mM}$ potassium phosphate buffer, $\mathrm{pH} 7.5$ was added, and equilibrated to $37^{\circ} \mathrm{C}$ for $5 \mathrm{~min}$. To this mixture, $100 \mu \mathrm{l}$ of protease was added and was incubated exactly $30 \mathrm{~min}$ at $37^{\circ} \mathrm{C}$ in a shaking water bath. Controls were prepared by the same procedure in absence of enzyme. After incubation, the suspension was immediately filtered through $0.45 \mu \mathrm{m}$ syringe filters, and the absorbance of the filtered solution was determined at $520 \mathrm{~nm}$. One unit is defined as the amount of enzyme which catalyses the release of azo dye causing an absorbance change of $1.0 \mathrm{~min}^{-1}$.

\subsection{Keratin azure assay}

Hydrolysis of keratin azure (Sigma-Aldrich) by B. cereus protease was determined according to the method of Wainwright [20]. The reaction mixture comprising $200 \mu \mathrm{l}$ of enzyme solution and $20 \mathrm{mg}$ of keratin azure in $50 \mathrm{mM}$ sodium phosphate buffer $\mathrm{pH} 7.5$, in a total volume of $5 \mathrm{ml}$ was incubated at $37^{\circ} \mathrm{C}$ with constant shaking over $26 \mathrm{~h}$ period. The unreacted soluble substrate was removed by centrifugation at $8000 \times g$ for $5 \mathrm{~min}$ and the liberation of the azo-dye in the supernatant was measured at $595 \mathrm{~nm}$. One unit of keratinolytic activity was defined as the amount of enzyme that led to an increase in $A_{595} \mathrm{~nm}$ of 0.01 after 30 min under the standard assay conditions.

\subsection{Protease assays with synthetic substrates}

Activity with pNA substrates was tested at $30^{\circ} \mathrm{C}$ in $50 \mathrm{mM}$ Tris- $\mathrm{HCl}$ buffer, $\mathrm{pH}$ 8.0. The substrate was prepared just before the experiment since nitroanilide substrates show varying degrees of autolysis during storage.

The pNA substrates used were: L-Leucine-pNA $(1.0 \mathrm{mM}), \mathrm{N}$-SuccinylAla-Ala-Pro-Phe-pNa (1.0 mM), $N$-Succinyl-Gly-Gly-Phe-pNA $(3.0 \mathrm{mM})$, $N$-Succinyl-Ala-Ala-Ala-pNA $(3.0 \mathrm{mM}), \quad N$-Succinyl-Ala-Ala-Pro-Leu-pNA $(1.0 \mathrm{mM}), N$-Succinyl-Gly-Gly-Gly-pNA $(2.5 \mathrm{mM})$, Sar-Pro-Arg-pNA dihydrochloride $(3.0 \mathrm{mM})$ and BAPNA $(3.0 \mathrm{mM})$. The increase in absorbance due to the hydrolysis and release of $p$-nitroanilide was measured at $400 \mathrm{~nm}$. Extinction coefficient $(\varepsilon)$ was taken to be $10500 \mathrm{M}^{-1} \mathrm{~cm}^{-1}$ at $\mathrm{pH} 8.0$. One unit of activity is defined as the amount of the enzyme that catalysis the transformation of $1 \mu \mathrm{mol}$ substrate per minute.

Hydrolytic activity of $B$. cereus protease with esters substrates was performed at $30^{\circ} \mathrm{C}$ in $50 \mathrm{mM}$ Tris- $\mathrm{HCl}$ buffer, $\mathrm{pH}$ 7.5. The substrates with the respective concentration used for the activity were: BAEE, $4.0 \mathrm{mM} \quad\left(\varepsilon_{253}=1150 \mathrm{M}^{-1} \mathrm{~cm}^{-1}\right) ;$ BTEE, $2.0 \mathrm{mM} \quad\left(\varepsilon_{256}=964 \mathrm{M}^{-1} \mathrm{~cm}^{-1}\right)$; ATEE, $3.0 \mathrm{mM}\left(\varepsilon_{237}=-0.0075 \mathrm{ml} \mu \mathrm{mol}^{-1} \mathrm{~cm}^{-1}\right)$; 4-nitrophenyl acetate and 4-

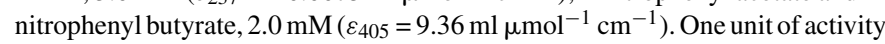
is defined as the amount of the enzyme that splits of $1 \mu \mathrm{mol}$ substrate per minute.

Protease activity using furylacryloylpeptidyl amides was determined according to the method described by Feder et al. [21]. The assay was carried out using $100 \mu \mathrm{l}$ of enzyme solution and $1 \mathrm{mM}$ of substrate at $30^{\circ} \mathrm{C}$. The stock solution $(10 \mathrm{mM})$ of the substrates was prepared by adding DMSO in a sufficient amount for dissolving the substrates and then the final volume was done with $50 \mathrm{mM}$ Tris- $\mathrm{HCl}$ buffer, $\mathrm{pH} 7.2$, containing $50 \mathrm{mM} \mathrm{Mes,} 2 \mathrm{mM} \mathrm{CaCl}_{2}$ and $0.01 \%$ Triton$\mathrm{X}-100$. The absorbance was recorded by continuously monitoring the decrease at $340 \mathrm{~nm}$ for $5 \mathrm{~min}$. The extinction coefficients were $\varepsilon_{340}=-0.600 \mathrm{ml} \mu \mathrm{mol}^{-1}$ for $N$-(3-[2-Furyl]acryloyl)-Ala-Phe amide and $\varepsilon_{340}=-0.359 \mathrm{~m} \mu \mathrm{mol}^{-1}$.

\subsection{Determination of the kinetic parameters}

The kinetic parameters were determined for the following substrates: LLeucine-pNA (0.05-1.0 mM), $N$-Succinyl-Ala-Ala-Pro-Phe-pNa $(0.1-1.0 \mathrm{mM})$, $N$-Succinyl-Ala-Ala-Pro-Leu-pNA $\quad(0.4-2.5 \mathrm{mM}), \quad N$-Succinyl-Gly-Gly-GlypNA $(0.4-2.5 \mathrm{mM}), \quad N$-Succinyl-Gly-Gly-Phe-pNA $(0.8-4.0 \mathrm{mM}), \quad N-(3-[2-$ Furyl]acryloyl)-Gly-Leu amide $(0.05-1.0 \mathrm{mM})$ and $N$-(3-[2-Furyl]acryloyl)Ala-Phe amide $(0.05-1.0 \mathrm{mM})$.

The kinetic studies were performed in triplicate and the data obtained fitted to the Michaelis-Menten equation. The $K_{\mathrm{m}}$ and $V_{\max }$ values were determined through non-linear regression analysis using the program Origin 5.0.

\subsection{Determination inhibition kinetics}

The inhibition kinetics were carried out with $N$-(3-[2-Furyl]acryloyl)-AlaPhe amide substrate at different inhibitor (EDTA) concentrations. The enzymecatalysed hydrolysis of the substrate $(1 \mathrm{mM})$ was followed in the absence of EDTA to establish the inhibited rate of substrate hydrolysis $\left(V_{0}\right)$. The inhibitor, EDTA was added in no more than $5 \%$ of the total assay volume. The reaction was allowed to procedure until the rate of hydrolysis has relaxed to a new steady state, thus establishing the inhibition rate $\left(V_{\mathrm{i}}\right)$. The substrate concentration was kept constant, by not allowing more than $5 \%$ hydrolysis. To have more accurate results, the experiment was repeated with several different concentrations of EDTA (0.001-0.3 mM). 


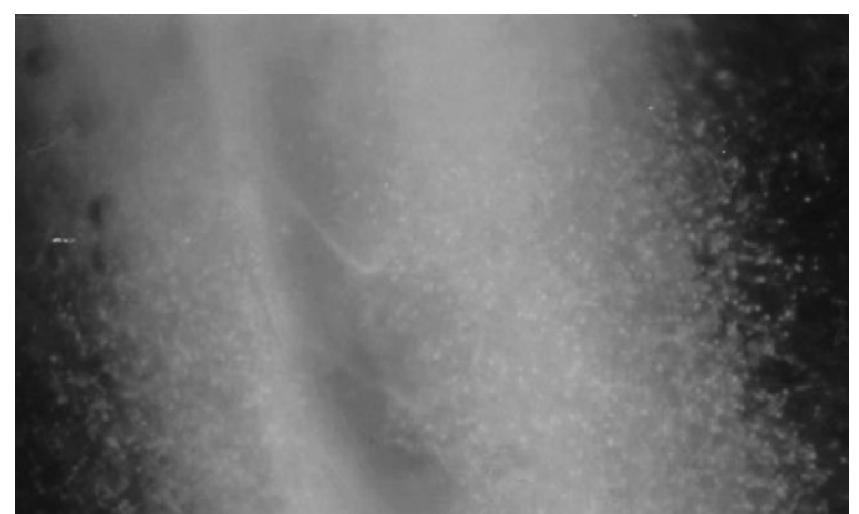

Fig. 1. Fluorescence microscopy images of the mixed population plated on overlaid wool agar plates.

\subsection{Determination of the specificity of $B$. cereus protease}

The proteolytic specificity of $B$. cereus protease was determined by analysis of the peptides obtained after incubation with the oxidized insulin B-chain as substrate.

Cleavage of oxidized insulin B-chain by the B. cereus protease at $37^{\circ} \mathrm{C}$ was investigated using an enzyme-substrate in a molar ratio of 1:100. The insulin

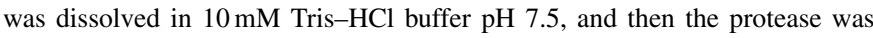
added. Samples were taken at different times, $30 \mathrm{~min}, 3,6,12$ and $24 \mathrm{~h}$. After incubation, the reaction $40 \mu \mathrm{l}$ of $0.1 \%$ TFA was added to inactivate the enzyme. Identification of the cleavage products were analysed by MALDI-TOF mass spectrometry and identified from their corresponding molecular masses. The cleavage was determined according Schecher and Berger [22].

\subsection{MALDI-TOF}

The digest of oxidized insulin B-chain by $B$. cereus protease was diluted $1: 10$ in $50 \%(\mathrm{v} / \mathrm{v})$ acetonitrile $/ 0.1 \%$ trifluoroacetic acid and mixed $1: 1$ with a $5 \mathrm{mg} \mathrm{ml}^{-1}$ solution of $\alpha$-cyano-4-hydroxycinnamic acid (Sigma-Aldrich) in $50 \%(\mathrm{v} / \mathrm{v})$ acetonitrile/0.1\% trifluoroacetic acid. One microlitre of the samples were spotted onto a stainless steel target MALDI plate and air-dried before analysis in the mass spectrometer. Identification of the cleavage products was performed on a matrix-assisted laser desorption ionization reflectron-type timeof-flight (MALDI-TOF) mass spectrometer (Waters ${ }^{\circledR}$ Micromass ${ }^{\circledR}$ MALDI micro MX, Manchester, UK), equipped with a $337 \mathrm{~nm}$ nitrogen laser. Spectra were acquired in the reflectron positive mode and calibration was carried out using a mixture of PEG oligomers. Cleavage sites were identified using the ExPASy tool findpept.

\section{Results and discussion}

\subsection{Isolation and screening of microorganisms}

From the 30 bacterial strains isolated from wool (Fig. 1), one strain was selected based on the proteolytic activity produced in skim milk agar plates and growth in a minimal medium with wool as the only source of carbon and nitrogen. Based on

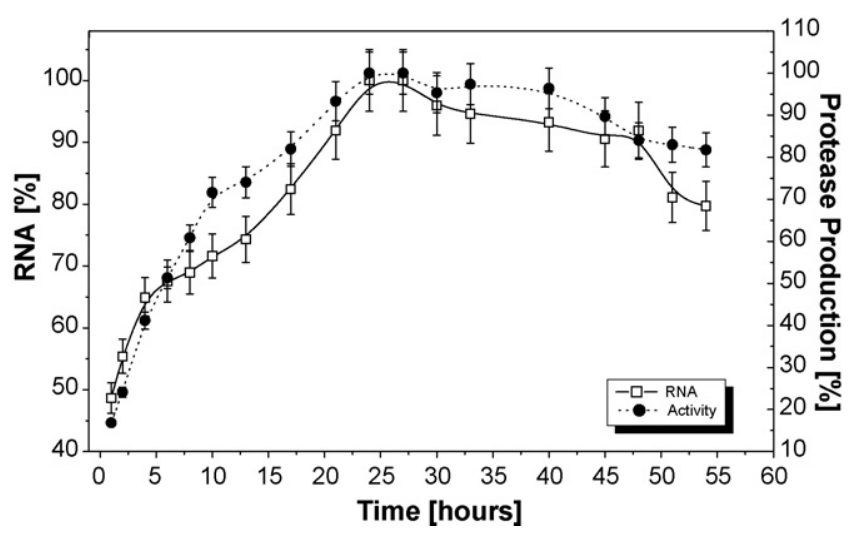

Fig. 2. Cell growth (RNA) and protease production of B. cereus. Cultivation of B. cereus was done in wool medium $\mathrm{pH} 7.0$ at $30^{\circ} \mathrm{C}$. Standard deviation based on triplicate data.

the relationship between the level of protease production and growth, the selected microorganism was identified as $B$. cereus (DSMZ, Braunschweig, Germany). B. cereus is a ubiquitous Gram-positive, spore-forming, motile rod, commonly found in soil, plant material, hay, raw and processed food. It is also frequently found in pasteurised milk, causing spoilage because of the production of lipases and proteases [23]. B. cereus grew and produced a protease using wool as sole of carbon and nitrogen (Fig. 2). Complete degradation of wool protein was observed after $55 \mathrm{~h}$, indicating that wool was used as an inducer for protease production. Peptides or proteins have been reported to increase proteases synthesis in a number of microorganisms [24]. The maximum enzyme activity was reached after $24 \mathrm{~h} \mathrm{incu-}$ bation and prolongation of the fermentation was accompanied with a gradual decrease of enzyme activity. From the growth curve of B. cereus based on the RNA content, it can be seen that protease production is correlated with growth. Secretion of proteases has been linked to the bacterial growth either associated with the growth or with stationary phase, with greatest expression of protease during the stationary phase, when sporulation also occurs [28]. To determine the number of proteases produced by $B$. cereus, an SDS-PAGE on a gel that was copolymerised with casein (zymogram) was performed (Fig. 3a). Extracellular proteases are common among Bacillus genus. However, in contrast to other Bacillus sp., B. cereus according to zymography, the presence of a single clear zone in the blue background suggests that the crude filtrate of $B$. cereus mainly contains a single protease.

B. cereus protease was purified to electrophoretic homogeneity by the combination of three chromatographic steps. In the first step using hydrophobic interaction chromatography, $98 \%$ of original protein was removed (Table 1). From the purification

Table 1

Summary of the purification of B. cereus protease from the lyophilized culture supernatant

\begin{tabular}{lcccccc}
\hline Purification step & Volume $[\mathrm{ml}]$ & Total protein $[\mathrm{mg}]$ & Total activity [nKat] & Specific activity [nKat mg ${ }^{-1}$ ] & Purification [fold] & Yield [\%] \\
\hline Crude lyophilized & 200.0 & 669.6 & 1422.9 & 2.1 & 1.0 & 100.0 \\
Hic phenyl & 20.0 & 12.3 & 400.1 & 32.7 & 15.3 & 28.1 \\
Desalting & 10.0 & 2.3 & 267.7 & 116.4 & 54.7 & 18.8 \\
Gel filtration & 2.0 & 0.3 & 30.7 & 122.7 & 57.6 & 2.16 \\
\hline
\end{tabular}



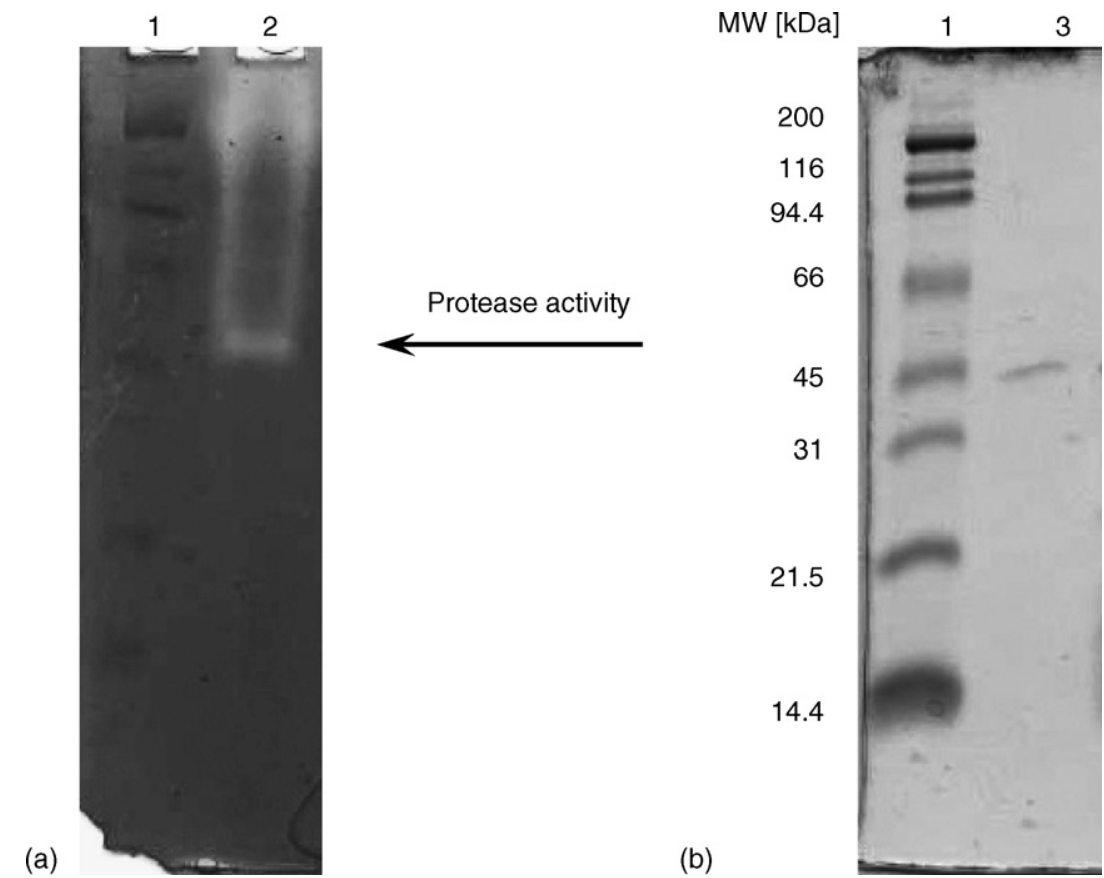

Fig. 3. (a) Zymogram analysis of proteases in the culture supernatant, in $12 \%$ polyacrylamide gel with copolymerized casein. The clear zone in the blue background is the result of enzymatic action. (b) SDS-PAGE with $12 \%$ acrylamide of the purified B. cereus protease. Lane 1, molecular weight standards (broad range), lane 2 , culture supernatante and lane 3 and $B$. cereus protease with a molecular weight of $45.6 \mathrm{kDa}$.

table, the protease was purified to 57.6 -fold with a $2.16 \%$ yield. The specific activity of the final enzyme preparation was estimated to be $122.7 \mathrm{nKat} \mathrm{mg}^{-1}$. In gel filtration chromatography, proteolytic activity was detected in a single peak corresponding and SDS-PAGE showed the homogeneity of the purified enzyme with a molecular weight of $45.6 \pm 1.7 \mathrm{kDa}$ (Fig. $3 \mathrm{~b}$ ). The molecular weight of $B$. cereus protease is in agreement with data from the literature indicating the molecular masses of previously works found proteases are rarely more than $50 \mathrm{kDa}$ [25-27].

\subsection{Biochemical characterization}

The optimum $\mathrm{pH}$ of $\mathrm{B}$. cereus protease at $37^{\circ} \mathrm{C}$ was determined to be 7.0. Bacteria of the Bacillus genus secrete mostly two types of extracellular proteases, a neutral or metalloprotease, and an alkaline protease which is functionally a serine endopeptidase, referred to as subtilisin. The first exhibit optimal $\mathrm{pH}$ at 7.0, whereas the latter have $\mathrm{pH}$ optima between 9 and 11 [31]. The protease from B. cereus belongs to the first group since the optimum $\mathrm{pH}$ was 7.0. However, this protease has new characteristics when compared to the others produced by B. cereus until now published.

The enzyme has a temperature optimum at $45^{\circ} \mathrm{C}$ and retains $55 \%$ of activity at $50^{\circ} \mathrm{C}$ after $2 \mathrm{~h}$ incubation (the half-life time at $50^{\circ} \mathrm{C}$ was $2 \mathrm{~h}$ ) and is stable in a wide range of $\mathrm{pH}$, retaining $85 \%$ of its original activity between $\mathrm{pH} 6$ and 9 after $1 \mathrm{~h}$ at $37^{\circ} \mathrm{C}$. At $\mathrm{pH} 5$, the half-life time $\left(37^{\circ} \mathrm{C}\right)$ was $1 \mathrm{~h}$.

In addition, the biochemical characterization and inhibition pattern provides clear results for the classification of the protease produced by B. cereus. The serine protease inhibitors (aprotinin and PMSF), cysteine protease inhibitor (E-64) and aspartic protease inhibitor (pepstatin) were ineffective as inhibitors. However, the metal chelators 1,10-phenantroline and EDTA caused $100 \%$ inactivation of enzyme. The strong inhibition observed against these inhibitors demonstrates that the purified protease is a metalloprotease (the results are summarized in Table 2). This was confirmed by studying the effect of EDTA on enzyme inhibition (data not shown) in which the enzyme is inhibited by even with low concentrations of EDTA, showing that $0.25 \mathrm{mM}$ EDTA was needed to cause $50 \%$ drop $\left(I_{50}\right)$ in $B$. cereus protease activity. This inhibition pattern is typical of met-

Table 2

Effect of inhibitors and metal ions on protease activity

\begin{tabular}{lcc}
\hline Substance & Concentration & Residual activity [\%] \\
\hline Control & $1 \mathrm{mM}$ & 100 \\
1,10-Phenantroline & $1 \mathrm{mM}$ & 0 \\
EDTA & $1 \mathrm{mM}$ & 0 \\
PMSF & $10 \mu \mathrm{M}$ & 164.8 \\
Aprotinin & $1 \mathrm{mM}$ & 100 \\
E-64 & $1 \mu \mathrm{M}$ & 153.7 \\
Pestatin A & $3 \mathrm{mM}$ & 98.1 \\
$\mathrm{Ca}^{2+}$ & & 117.9 \\
$\mathrm{Zn}^{2+}$ & & 70.6 \\
$\mathrm{Cu}^{2+}$ & & 5.5 \\
$\mathrm{Mg}^{2+}$ & & 98.0 \\
$\mathrm{Mn}^{2+}$ & & 104.6 \\
$\mathrm{Fe}^{3+}$ & & 66.0 \\
$\mathrm{Li}^{+}$ & & 95.4 \\
$\mathrm{~K}^{+}$ & & 62.0 \\
$\mathrm{Co}^{2+}$ & & 93.4 \\
\hline
\end{tabular}

The residual activity was measured after pre-incubation of B. cereus protease with the different substances. 
alloproteases and suggests that in the B. cereus, unlike Bacillus subtillis, proteolytic activity when grown on wool is a result of neutral protease.

Calcium ions were found to enhance protease activity, achieving its maximum activity at a concentration of $10 \mathrm{mM}$, while $\mathrm{Cu}^{2+}$ decreased the activity to $5.5 \%$ (see Table 2 ). These results indicated that the enzyme require $\mathrm{Ca}^{2+}$ for its optimal activity. Since $\mathrm{Ca}^{2+}$ is the best inducer, the effect of its concentration on protease activity and the maximum activity was obtained with $10 \mathrm{mM} \mathrm{Ca}^{2+}$ (data not shown). The effect of $\mathrm{Ca}^{2+}$ on the protease under investigation may involve stabilization of the enzyme molecule structure. Calcium cations are known to be stabilizers of many enzymes, protecting them from conformational changes. The $\mathrm{Ca}^{2+}$ binding sites examined for some bacterial proteases contain a number of co-coordinating aspartate and glutamate residues [29].

Several reports show that proteolytic activity could be enhanced by the addition of organic solvents in the reaction mixture [30]. However, enzymes are usually inactivated or denatured in the presence of organic solvents. The protease showed good stability in the presence of DMSO $(20 \mathrm{mM})$ and acetonitrile $(1 \mathrm{mM})$, since the activity increase approximately 5 and $3 \%$, respectively, when compared to the enzyme in the absence of an organic solvent (see Table 3 ). The protease activity was rapidly inhibited in presence of $2 \% \mathrm{SDS}$; however, showed

Table 3

Effect of solvents, detergents and reducing agents on B. cereus protease activity, after pre-incubation for $30 \mathrm{~min}$ at $37^{\circ} \mathrm{C}$

\begin{tabular}{|c|c|c|c|}
\hline Substance group & Substance & $\begin{array}{l}\text { Concentration } \\
{[\%]}\end{array}$ & $\begin{array}{l}\text { Residual } \\
\text { activity [\%] }\end{array}$ \\
\hline Control & & & 100 \\
\hline \multirow[t]{6}{*}{ Detergents } & SDS & 0.1 & 23.66 \\
\hline & & 0.5 & 11.56 \\
\hline & & 2.0 & 0.36 \\
\hline & Triton X-100 & 0.1 & 94.13 \\
\hline & & 0.5 & 91.81 \\
\hline & & 2.0 & 87.72 \\
\hline \multirow[t]{9}{*}{ Organic solvents } & DMSO & 1.0 & 93.06 \\
\hline & & 5.0 & 100.00 \\
\hline & & 20.0 & 105.16 \\
\hline & Isopropanol & 1.0 & 92.88 \\
\hline & & 5.0 & 87.37 \\
\hline & & 20.0 & 69.93 \\
\hline & Acetonitrile & 1.0 & 103.20 \\
\hline & & 5.0 & 90.57 \\
\hline & & 20.0 & 91.81 \\
\hline \multirow[t]{9}{*}{ Reducing agents } & DTT & 0.5 & 5.34 \\
\hline & & 2.0 & 1.07 \\
\hline & & 8.0 & 0.18 \\
\hline & $\beta$-Mercaptoethanol & 0.5 & 27.40 \\
\hline & & 2.0 & 4.80 \\
\hline & & 8.0 & 0.89 \\
\hline & Thioglycolate & 0.5 & 45.20 \\
\hline & & 2.0 & 2.85 \\
\hline & & 8.0 & 1.78 \\
\hline
\end{tabular}

some stability in presence of Triton X-100. Reducing agents like DTT inhibited the enzyme even at low concentrations, with $\beta$-mercaptoethanol and thioglycolate the enzyme retained 27 and $45 \%$ of its initial activity, respectively, above these concentrations the enzyme was rapidly inhibited. From our study, it can be concluded that the stability of $B$. cereus protease depends on the nature of organic solvents, as well as the nature of detergents. This means that replacement of some water molecules in an enzyme with organic molecules sometimes stabilizes the structure of the enzyme [31]. A similar increase in protease activity from $P$. aeruginosa PST-01 was also reported by Ogino et al. [32] when the enzyme was pre-incubated in the presence of water miscible organic solvents.

\subsection{Hydrolysis of various protein substrates}

The activity of $B$. cereus protease was tested with different soluble and insoluble proteinaceous substrates at $37^{\circ} \mathrm{C}$ for $30 \mathrm{~min}$. The enzyme hydrolysed azocasein and azocoll efficiently, exhibiting 216.04 and $355.63 \mathrm{nKat} \mathrm{mg}^{-1}$, respectively, under similar conditions. The keratinolytic activity $12.45 \mathrm{nKat} \mathrm{mg}^{-1}$ was significantly lower than the obtained with the other protein substrates.

\subsection{Determination of the cleavage specificity}

The proteolytic specificity of $B$. cereus protease was determined by analysis of the peptides obtained after incubation with the oxidized insulin B-chain as substrate. Cleavage of oxidized insulin B-chain by the $B$. cereus protease at $37^{\circ} \mathrm{C}$ was investigated using an enzyme-substrate in a molar ratio of 1:100. The reaction products after incubation from $30 \mathrm{~min}$ up to $24 \mathrm{~h}$ were analysed by MALDI-TOF mass spectrometry and identified from their corresponding molecular masses. From the peptides obtained after the hydrolysis of the oxidized insulin B-chain by B. cereus protease, the enzyme showed endopeptidase activity and a broad specificity, a total of seven peptide bonds in the B-chain of insulin were hydrolysed (Fig. 4). The complete hydrolysis was reached after $12 \mathrm{~h}$ incubation, however all larger cleavages were detected after $30 \mathrm{~min}$ incubation. The

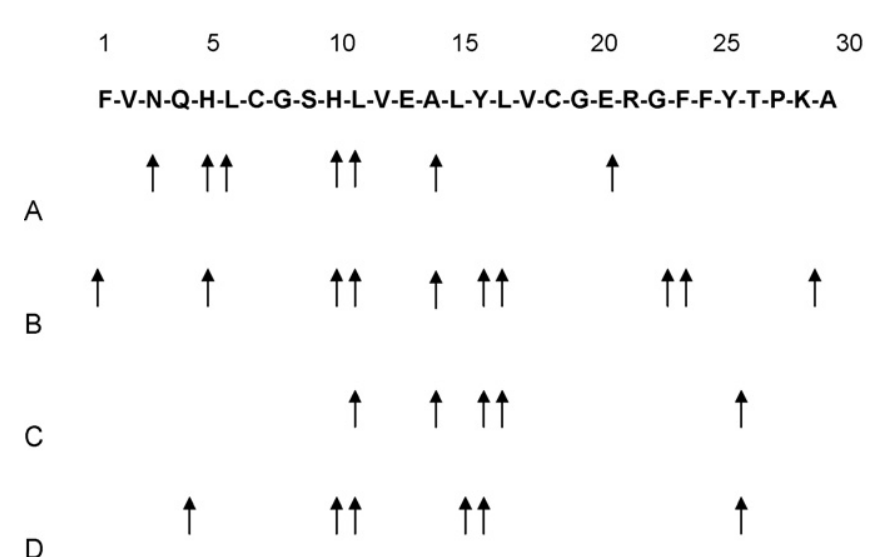

Fig. 4. Specificity of B. cereus protease (A) for oxidized insulin B-chain, in comparison to thermolysin (B) [37], camelysin (C) [12] and subtilisin (D) [36]. 
Table 4

Hydrolysis of peptide derivates by B. cereus protease

\begin{tabular}{llc}
\hline Substrate & Recommended use & Activity $\left[\mathrm{nKat}^{-1} \mathrm{C}^{-1}\right.$ \\
\hline L-Leucine-pNA & Leucine aminpeptidase & 0.145 \\
$N$-Succinyl-Ala-Ala-Pro-Phe-pNa & Chymotrypsin, Cathepsin G & 0.216 \\
$N$-Succinyl-Gly-Gly-Phe-pNA & Chymotrypsin, S. griseus protease B & 0.010 \\
$N$-Succinyl-Ala-Ala-Ala-pNA & Elastase & Negligible small \\
$N$-Succinyl-Ala-Ala-Pro-Leu-pNA & Elastase & 0.069 \\
$N$-Succinyl-Gly-Gly-Gly-pNA & & 0.015 \\
$N$-(3-[2-Furyl]acryloyl)-Gly-Leu amide & Thermolysin & 49.61 \\
$N$-(3-[2-Furyl]acryloyl)-Ala-Phe amide & Thermolysin & 203.45 \\
Sar-Pro-Arg-pNA dihydrochloride & Thrombin & 0.013 \\
BAPNA & Trypsin & No activity \\
BAEE & Trypsin & No activity \\
BTEE & & No activity \\
ATEE & Chymotrypsin & No activity \\
4-Nitrophenyl acetate & Esterase & No activity \\
4-Nitrophenyl butyrate & Esterase & No activity \\
\hline
\end{tabular}

major requirement is that a hydrophobic residue such as Leu, Val or Ala should participate with the $\mathrm{N}$-amino group in the bond to be cleaved. However, hydrolysis of bonds at the N-terminal side of His, Cys and Glu was also observed. The residue in the bond by the carboxyl group may have a stimulating effect; the cleavage is favoured with polar groups at the N-terminal. This cleavage is different from other metalloproteases reported; the cleavage pattern is clearly different from that of thermolysin [37] and camelysin [12]. Only four cleavage sites were in common with thermolysin and two for camelysin (which is a metalloprotease from $B$. cereus). The peptide bond $\mathrm{Leu}^{15}-\mathrm{Tyr}^{16}$ in the oxidized insulin B-chain, which is the major cleavage product obtained from the alkaline proteases are resistant to the attack of $B$. cereus protease and other neutral proteases $[35,36]$.

\subsection{Substrate specificities}

Amino acids in the position $\mathrm{P}_{1}$ have a strong influence in the catalytic action of the enzyme, see Table 4 . The B. cereus protease showed preference for Leucine and Phenylalanine amino acids at the position $\mathrm{P}_{1}$ and exhibited the highest activity for L-Leucine-pNA $\left(0.145 \mathrm{nKat} \mathrm{mg}^{-1}\right), N$-Succinyl-Ala-AlaPro-Phe-pNa $\left(0.216 \mathrm{nKat} \mathrm{mg}^{-1}\right)$, L-Leucine-pNA and with $\mathrm{N}$-Succinyl-Ala-Ala-Pro-Leu-pNA $\left(0.069 \mathrm{nKat} \mathrm{mg}^{-1}\right)$. Low or very low hydrolysis was detected when Ala or Gly where the amino acids residues at position $\mathrm{P}_{1}$ ( $N$-Succinyl-AlaAla-Ala-pNA or $N$-Succinyl-Gly-Gly-Gly-pNA). However, for $N$-Succinyl-Gly-Gly-Phe-pNA, the rate of hydrolysis decreased indicating that the amino acid in position $\mathrm{P}_{2}$ has influence in the catalytic activity.

B. cereus protease exhibited no esterolytic activity towards $p$ nitrophenyl esters. Shorter peptide substrates such as L-LeucinepNA were good substrates for this enzyme.

To investigate the effects of the amino acid residues adjacent to the sensitivity for Leucine and Phenylalanine residues in peptide substrates more in detail, a kinetic study was undertaken using various synthetic peptides. These peptides were all split at the peptide bond containing the amino group of Leucine and Phenylalanine, see Table 5.

The nature of the amino acid in the position $\mathrm{P}_{2}$ also influenced the specificity for the specificity in the position $\mathrm{P}_{1}$. This can be seen from the difference of the kinetic parameters when comparing the substrates $N$-Succinyl-Ala-Ala-Pro-Phe-pNa $\left(K_{\mathrm{cat}} / K_{\mathrm{m}}\right.$, $\left.0.24 \mathrm{mM}^{-1} \mathrm{~s}^{-1}\right)$ and $N$-Succinyl-Gly-Gly-Phe-pNA $\left(K_{\text {cat }} / K_{\mathrm{m}}\right.$ $0.040 \mathrm{mM}^{-1} \mathrm{~s}^{-1}$ ); when Proline is substituted by Glycine, the $K_{\text {cat }} / K_{\mathrm{m}}$ decreases confirming the influence of amino acid residue present at position $\mathrm{P}_{2}$. These characteristics of specificity have been found for thermolysin and for other neutral proteases from bacterial origin, which are optimally active at neutral $\mathrm{pH}$ and are inhibited by EDTA [37]. The results indicate that the $B$. cereus protease is very similar to thermolysin not only in the specificity against $\mathrm{P}_{1}$ position but also with regard to the effects of amino acids residues neighbouring the site of cleavage. However, some differences where observed in the side chain specificity at $\mathrm{P}_{2}$. At $\mathrm{P}_{2}$ in $B$. cereus protease, Proline promotes the hydrolysis while for thermolysin this was not observed.

Table 5

Kinetic parameters of the $\mathrm{BC}$ protease with selected synthetic substrates

\begin{tabular}{lcccc}
\hline Substrate & $V_{\max }\left[\mathrm{nKat} \mathrm{mg}^{-1}\right]$ & $K_{\mathrm{m}}[\mathrm{mM}]$ & $K_{\text {cat }}\left[\mathrm{s}^{-1}\right]$ & 0.079 \\
\hline L-Leucine-pNA & 0.158 & 0.187 & 0.19 & 0.42 \\
$N$-Succinyl-Ala-Ala-Pro-Phe-pNa & 0.371 & 0.785 & 0.12 & 0.24 \\
$N$-Succinyl-Ala-Ala-Pro-Leu-pNA & 0.244 & 1.253 & 0.065 & 0.097 \\
$N$-Succinyl-Gly-Gly-Gly-pNA & 0.129 & 2.626 & 0.058 & 0.025 \\
$N$-Succinyl-Gly-Gly-Phe-pNA & 0.115 & 1.335 & 131.30 & 0.040 \\
$N$-(3-[2-Furyl]acryloyl)-Gly-Leu amide & 262.73 & 2.363 & 203.15 \\
$N$-(3-[2-Furyl]acryloyl)-Ala-Phe amide & 406.50 & 0.858 & 236.80 \\
\hline
\end{tabular}



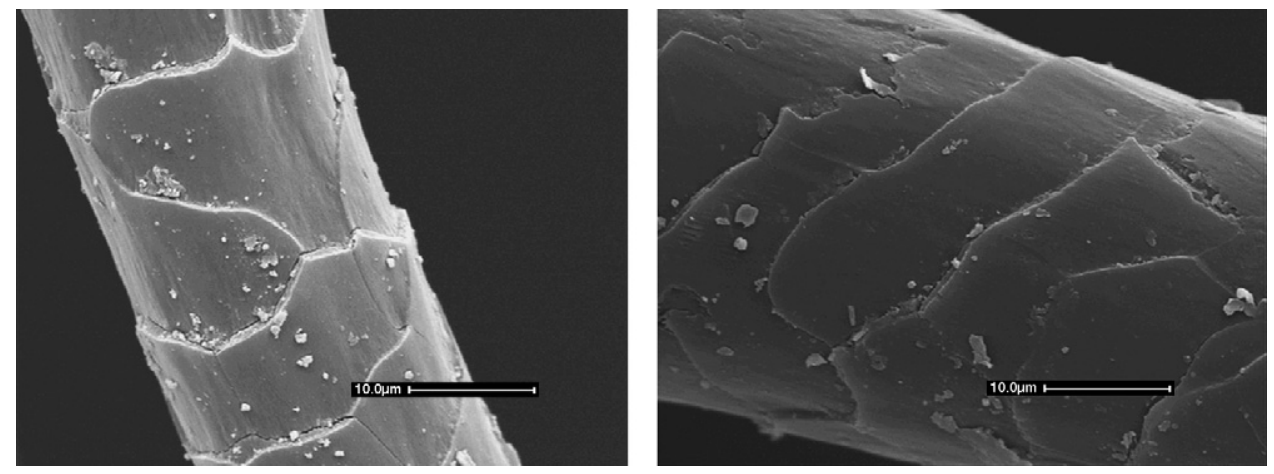

Fig. 5. High resolution scanning electron microscope image of wool surface after treatment with $B$. cereus protease $(25,000 \times$ magnification $)$.

Interestingly, Phe at the N-terminal side of the insulin Bchain did not show any effect on the hydrolysis while with the synthetic substrates the $B$. cereus protease show higher efficiency with $\mathrm{Phe}$ at this position. A possible explanation is due to the influence of other amino acids at positions $\mathrm{P}_{2}^{\prime}, \mathrm{P}_{3}^{\prime}$, etc., as well as at the positions $\mathrm{P}_{2}, \mathrm{P}_{3}$, etc. Based on its hydrolytic activity towards $N$-(3-[2-Furyl]acryloyl)-Gly-Leu amide and $N$ (3-[2-Furyl]acryloyl)-Ala-Phe amide, the B. cereus protease has identical substrate specificity as thermolysin, showing the highest kinetic for $N$-(3-[2-Furyl] acryloyl)-Ala-Phe amide $\left(K_{\text {cat }} / K_{\mathrm{m}}\right.$ $\left.236.84 \mathrm{mM}^{-1} \mathrm{~s}^{-1}\right)$ and $N$-(3-[2-Furyl]acryloyl)-Gly-Leu amide $\left(K_{\mathrm{cat}} / K_{\mathrm{m}} 55.60 \mathrm{mM}^{-1} \mathrm{~s}^{-1}\right)$ as substrates. Except for its lower thermostability, the $B$. cereus protease has some similarity to thermolysin, with respect to substrate specificity and the presence of zinc (data not shown) in the molecule which is required for activity [33]. However, unlike thermolysin, it does not exhibit considerable elastolytic activity [34]. On the other hand, like thermolysin ( $\mathrm{pH}$ optimum between 7 and 9) it shows a broad $\mathrm{pH}$ optimum between 6 and 8.5. This study somewhat clarified the effects of some several neighbouring amino acid residues surrounding the susceptible peptide bond on the appearance of the specificity of $B$. cereus protease.

The inhibition constant $\left(K_{\mathrm{i}}\right)$ was calculated with $\mathrm{N}$-(3-[2Furyl]acryloyl)-Ala-Phe amide as substrate at different inhibitor (EDTA) concentrations. This substrate was selected for the inhibition kinetics, due to the high affinity of the enzyme toward this substrate. One important consideration in this assay was that the substrate was kept constant by not allowing more than $5 \%$ of hydrolysis. The $K_{\mathrm{i}}$ value $(0.971 \mathrm{mM})$ is almost the same as the $K_{\mathrm{m}}(0.858 \mathrm{mM})$ value of the corresponding substrate. On the other hand, the $V_{\max }\left(406.50 \mathrm{nKat} \mathrm{mg}^{-1}\right)$ significantly decreased $\left(V_{\text {imax }} 213.93 \mathrm{nKat} \mathrm{mg}^{-1}\right)$, indicating non-competitive inhibition.

\subsection{Hydrolysis of wool}

Wool keratins are characterized by a high degree of crosslinked disulfide bonds, hydrophobic interactions and hydrogen bonds which stabilizes keratin filament structure [4]; which are very difficult to proteolytic attack. SEM analysis (Fig. 5) showed that $B$. cereus protease hydrolysed the cuticles on wool surface. An interesting effect is that somehow the enzyme "cracked" the wool surface.

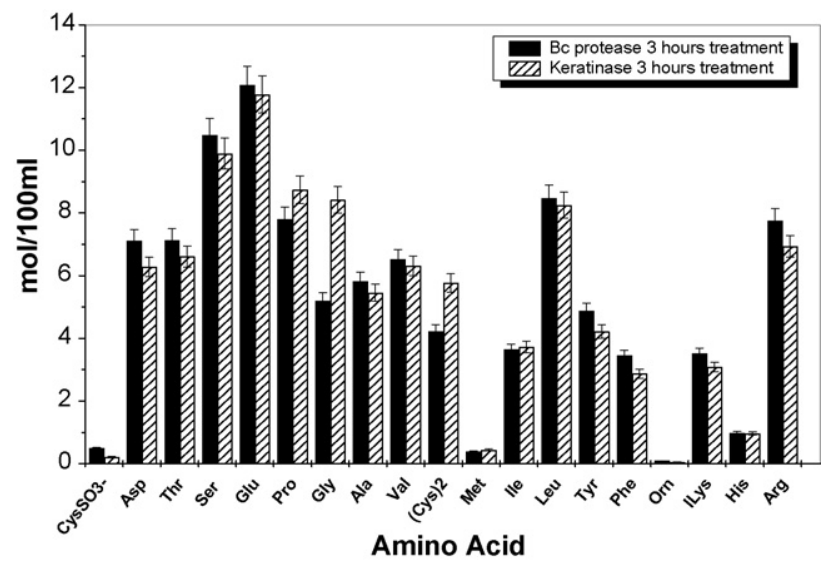

Fig. 6. Comparison of the amino acids composition of hydrolysed wool after 3-h treatment with B. cereus protease and keratinase. Standard deviation based on triplicate data.

The action of B. cereus protease on wool was done in comparison with a keratinase (Fig. 6), which are a group of proteolytic enzymes able to hydrolyse insoluble keratins more efficiently than other proteases. After the enzymatic treatment, the wool was completely hydrolysed and the amino acid analysed. Amino acid content analysis of wool after treatment with this protease shows a reduction of the cystine content, which is the main content of the wool cuticle, as well in the total amino acid content. The cystine content on wool after treatment with $B$. cereus protease is much lower after $3 \mathrm{~h}$ than with keratinase treatment. The amount of the total amino acids of wool after $B$. cereus protease treatment $(75.3 \mathrm{nmol})$ is much lower than the one with keratinase treatment $(88.9 \mathrm{nmol})$. This indicates that $B$. cereus protease has higher catalytic activity towards wool than keratinase. The results showed that there was no significant differences between $B$. cereus protease and keratinase-treated wool, which can be said that $B$. cereus protease is a keratinase-type.

\section{Conclusion}

In this work, several different bacteria growing on wool samples were isolated. B. cereus was selected based on the level protease production and growth toward wool.

B. cereus protease was purified to electrophoretic homogeneity using a combination of three chromatographic steps. 
SDS-PAGE showed the homogeneity of the purified enzyme with a molecular weight of $45.6 \pm 1.7 \mathrm{kDa}$.

The extracellular protease produced by $B$. cereus exhibits optimal $\mathrm{pH}$ at 7.0 and optimum temperature at $45^{\circ} \mathrm{C}$. This inhibition pattern is typical of metalloproteases. B. cereus protease has some similarity to thermolysin, with respect to substrate specificity, however the cleavage pattern of the oxidized insulin B-chain is clearly different from that of thermolysin.

Wool keratin is water insoluble and extremely resistant to degradation by proteolytic enzymes such as trypsin, pepsin and papain. However, from SEM images of wool treated with $B$. cereus protease, it was clear that this enzyme is able to degrade the wool surface.

The results of the action of $B$. cereus protease toward wool showed that $B$. cereus protease is a keratinase-type.

The results presented here, including some thermostability and activity over a wide range of $\mathrm{pH}$ values, stability against some organic solvents and detergents, hydrolysis of various protein substrates (such as azocasein, azocoll, keratin azure and wool), endopeptidase activity and broad specificity, demonstrate that $B$. cereus protease will most probably play an important role for the application in the anti-shrinking process efficiently hydrolysing wool cuticles. However, as we have described before, increasing the molecular weight of this enzyme by chemical modification will be necessary to target its action to the wool surface [38].

\section{Acknowledgements}

The authors acknowledge financial support from EU funding for Protex project (G1RDCT-2002-00695). We would like to thank the PROTEX project consortium for excellent collaboration and Doris Steifer for a great technical support.

\section{References}

[1] Zahn H, Schäfer K, Popescu C. Wool from animal sources. In: Steinbüchel A, Kaplan D, editors. Biopolymers. Polymides and complex proteins. Wiley-VCH Verlag; 2002. pp. 155-222.

[2] Höcker H. Fibre morphology. In: Simpson WS, Crawshaw GH, editors. Wool: science and technology. Cambridge, England: Woodhead Publishing Limited; 2002. p. 60-78.

[3] Hearle JWS. Physical properties of wool. In: Simpson WS, Crawshaw GH, editors. Wool: science and technology. Cambridge, England: Woodhead Publishing Limited; 2002. p. 80-126.

[4] Simpson WS. Wool chemistry. In: Simpson WS, Crawshaw GH, editors. Wool: science and technology. Cambridge, England: Woodhead Publishing Limited; 2002. p. 130-51.

[5] Halliday LA. Woolscouring, carbonization and effluent treatment. In: Simpson WS, Crawshaw GH, editors. Wool: science and technology. Cambridge, England: Woodhead Publishing Limited; 2002. p. 21-57.

[6] Pascual E, Julia MR. The role of chitosan in wool finishing. J Biotechnol 2001;89:289-96.

[7] Sawada K, Ueda M. Enzyme processing of textiles in reverse micellar solution. J Biotechnol 2001;89:263-9.

[8] Cortez J, Bonner PLR, Griffin M. Application of transglutaminases in the modification of wool textiles. Enzyme Microbial Technol 2004;34:64-72.

[9] Heine E, Höcker H. Enzyme treatments for wool and cotton. Rev Prog Coloration 1995;25:57-63.
[10] Cardamone JM. Proteolytic activity of Aspergillus flavus on wool. AATCC Rev 2002;2(5):30-5.

[11] Nurhan O, Sarnsik M. Use of enzymes and chitosan biopolymer in wool dyeing. Fibres Text East Eur 2005;13:49.

[12] Friecke B, Drößler K, Willhardt I, Schierhorn A, Menge S, Rücknagel P. The cell envelope bound metallopratease (camelysin) from Bacillus cereus is a possible pathogenic factor. Biochim Biophys Acta 2001;1537:13246.

[13] Benthin S, Nielsen J, Villadsen J. A simple and reliable method for the determination of the cellular RNA content. Biotechnol Tech 1991;5(1):3942.

[14] Herbert D, Phipps PJ, Strange RE. Chemical analysis of microbial cells. Methods Microbiol 1971;5B:209-344.

[15] Tomarelli RM, Charney J, Harding ML. The use of azoalbumin as a substrate in the colorimetric determination of peptic and tryptic activity. J Lab Clin Med 1949;34:428-33.

[16] Laemmli UK. Cleavage of structural proteins during the assembly of the head of bacteriophage T4. Nature 1970;227:680-5.

[17] Lowry OH, Rosebrough NJ, Farr AL, Randall RJ. Protein measurement with the folin phenol reagent. J Biol Chem 1951;193:265-75.

[18] Britton HTS, Robinson R. Universal buffer solutions and the dissociation constant of veronal. J Chem Soc 1931;458:1456.

[19] Chavira Jr R, Burnett TJ, Hageman JH. Assaying proteinases with azocoll. Anal Biochem 1984;136:446-50.

[20] Wainwright MA. A new method for determining the microbial degradation of keratin in soil. Experientia 1982;38:243-4.

[21] Feder J, Keay L, Garret LR, Cirulis N, Moseley MH, Wildi BS. Bacillus cereus neutral protease. Biochim Biophys Acta 1971;251(1):74-8.

[22] Schecher I, Berger A. On the size of active site in proteinase. I. Papain. Biochem Biophys Res Commun 1967;27:157-62.

[23] Kramer JM, Gilbert RJ. Bacillus cereus and other Bacillus species. In: Doyle MP, editor. Foodborne bacterial pathogens. New York and Basel: Marcel Dekker; 1989. p. 21-70.

[24] Priest FG, Harwood CR. Bacillus species. In: Hui YH, Kachatourians GG, editors. Food biotechnology: microorganisms. New York: VCH; 1994. p. $275-95$.

[25] Watanabe A, Kamio Y, Kimura W, Izaki K. Purification and characterization of a thermostable neutral metalloprotease I from Chioroflexus aurantiacus J-10-fl. Biosci Biotechnol Biochem 1993;57:2160-5.

[26] Dozie INS, Okeke CN, Unaeze NC. A thermostable alkaline active keratinolytic proteinase from Chrysosporium keratinophilum. World J Microbiol Biotechnol 1994;10:563-7.

[27] Klingberg M, Galunsky B, Sjohom C, Kasche V, Antranikian G. Purification and properties of a highly thermostable, sodium dodecyl sulfate-resistant and stereospecific protease from the extremely thermophilic archaeon Thermococcus stetteri. Appl Environ Microbiol 1995;61:3098-104.

[28] Priest FG. Extracellular enzyme synthesis in the genus Bacillus. Bacteriol Rev 1977;41:711-53.

[29] Vordouw G, Milo C, Roche RS. The role of bound calcium ions in thermostable proteolytic enzymes. Separation of intrinsic and calcium ions contribution to the kinetic thermal stability. Biochemistry 1976;15:3716-23.

[30] Gupta MN. Enzyme function in organic solvents. Eur J Biochem 1992;203:25-32.

[31] Ghorbel B, Sellami-Kamoun A, Nasri M. Stability studies of protease from Bacillus cereus BG1. Enzyme Microbial Technol 2003;32:513-8.

[32] Ogino $\mathrm{H}$, Uchiho $\mathrm{T}$, Yokoo J, Kobayashi R, Ichise R, Ishikawa $\mathrm{H}$. Role of intermolecular disulfide bonds of the organic solvent-stable PST01 protease in its organic solvent stability. Appl Environ Microbiol 2001;67:942-7.

[33] Matsubara H. Purification and assay of thermolysin. In: Perlmann GE, Lorand L, editors. Methods in enzymology. New York: Academic Press; 1970. p. 642-51.

[34] Morihara K, Tsuzuki H. Elastolytic properties of various proteinases from microbial origin. Arch Biochem Biophys 1967;120:68-78.

[35] Tsuchida O, Yamagata Y, Ishizuka T, Yamada JI, Takeuchi M. An alkaline protease of an alkalophilic Bacillus sp. Curr Microbiol 1986;4:7-12. 
[36] Tsuchiya K, Seki K, Arai T, Masui T. Substrate specificity of alkaline protease from Cephalosporium sp. KM 388. Biosci Biotechnol Biochem 1993;57:1803-4.

[37] Morihara K, Tsuzuki H. Thermolysin: kinetic study with oligopeptides. Eur J Biochem 1970;15:374-80.
[38] Schroeder M, Lenting HBM, Kandelbauer A, Silva CJSM, CavacoPaulo A, Guebitz GM. Restricting detergent protease action to surface of protein fibres by chemical modification. Appl Microbiol Biotechnol 2006;72:738-44. 